\title{
Sociological Debate on Inequalities in Russia and Beyond*
}

\author{
Alexandrina Vanke \\ Candidate of Sociological Sciences, Associate Professor, Department of Sociology, \\ State Academic University for the Humanities \\ Research Fellow, Institute of Sociology, Russian Academy of Sciences \\ Address: Krzhizhanovskogo str., 24/35, bld. 5, Moscow, Russian Federation 117259 \\ E-mail: alexandrina.vanke@gmail.com
}

\begin{abstract}
The review considers the $5^{\text {th }}$ All-Russian Sociological Congress held at the Ural Federal University in Yekaterinburg in October, 2016. The event, entitled "Sociology and Society: Social Inequality and Social Justice," attracted more than 1000 delegates from Russia and abroad. The Congress took place against a background of increasing social inequality in Russia, following the economic crisis of 2015. The program included 17 sessions, 37 panels, and 35 round tables which covered burning topics such as the unequal distribution of resources in Russian regions, the reduction of social welfare, the low living standards of vulnerable social groups, the growth of ethnic tension, and others. One of the plenary talks was given by the president of the International Sociological Association, Margaret Abraham, who spoke on the humanistic mission of Sociology, and called to coalesce in the struggle against social injustice in the world. The discussions at the Congress have shown that sociologists in Russia follow the global trends in examining urgent social problems, as well as in reflecting methodological issues, e.g., the application of new approaches in inequality studies. The debate on the restriction of academic freedoms in Russia at the closing plenary session made it obvious that the solution to this problem can be found in professional solidarity and is the responsibility of everyone who belongs to the sociological community.
\end{abstract}

Keywords: social inequality, precariat, social justice, social problems, sociological community, Sociology, Russian Sociology, International Sociology

The $5^{\text {th }}$ All-Russian Sociological Congress "Sociology and Society: Social Inequality and Social Justice," held on October 19-21 2016 in Yekaterinburg, was attended by more than 1000 delegates, not only from Russia but also from Belarus, Brazil, Kazakhstan, Kyrgyzstan, Latvia, the Ukraine, the USA, and other countries. The Congress was organized by the Russian Society of Sociologists, the Institute of Sociology of the Russian Academy of Sciences (IS RAS), and the Ural Federal University (UrFU). Despite the public attention to the event reflecting the current state of Sociology in Russia, the opinions about the event were different to some extent. To be substantive, I will cite some Facebook posts

(c) Ваньке А. В., 2017

(c) Центр фундаментальной социологии, 2017

DOI: $10.17323 / 1728-192 \mathrm{X}-2017-1-270-277$

* The conference review is prepared as a part of the project «Intergenerational Social Mobility from $20^{\text {th }}$ to $21^{\text {st }}$ Century: Four Generations of Russian History», supported by the Russian Science Foundation (Grant № 14-28-00217).

Обзор конференции подготовлен в рамках проекта «Межпоколенная социальная мобильность от XX века к XXI: четыре генерации российской истории», поддержанного Российским научным фондом (грант № 14-28-00217). 
with diverging views. Some colleagues who disregarded the Congress expressed their attitude in the following way: "[the answer to the question, if you were at the Congress] Of course not, I prefer visiting cemeteries than public gatherings of the living dead" (Ivan Nizgoraev, 21.10.2016). The positive impressions of the event were articulated by some sociologists who did come to Yekaterinburg: "Trips to conferences are always pleasing, with new contacts, information, even new projects. The Sociological Congress was not an exception. I made acquaintances with new colleagues in the session on childhood with great pleasure. There was an amazingly friendly... and comfortable atmosphere. Thanks for the constructive and fruitful dialogue..." (Olga Savinskaya, 25.10.2016). The third view considering the strengths and weaknesses of the Congress represents a differentiated approach to the event: "Scientific events range between two extremes: a collaboration of like-minded people where organizers insure against irrelevant and weak papers, or an absolute hodgepodge where anyone who has paid the conference fee is accepted... Both extremes are questionable. But what's undoubtedly true is that the sessions should be prepared... The sessions on the Internet and Longitudinal studies, which drifted towards a 'collaboration' according to the given scale, were well-prepared meetings" (Natalia Ve[selkova], 22.10.2016). But what was the Congress really like? I will try to answer this question in the review.

For me, it was the first time that I took part in the All-Russian Sociological Congress. Despite the criticism of some colleagues regarding the lack of organization and even professional backwardness, this participation gave me a fruitful experience for many reasons. The program of the Congress included 17 sessions, 37 panels, and 35 round tables covering such topics as social inequality in urban/regional development, social policy, social welfare, civil society, social movements, migration, health, ethnic tension, class structure, social mobility, and many others. Of course, it is impossible to outline all the themes which were discussed during the three days; however, some of them are presented in the more than 1300 papers of the proceedings of the Congress.

The opening ceremony of the Congress took place in the amazing hall of the main UrFU building decorated with columns in the neoclassical style and molded portraits of Karl Marx and Vladimir Lenin. The opening plenary session included greetings from local officials, the presidents and representatives of professional associations, as well as the organizers. I will briefly describe the most memorable moments. In her plenary speech, Margaret Abraham, the current president of the International Sociological Association, drew attention to the necessity of the critical examination of social inequalities affecting all spheres of social life. She stressed that Sociology should be open, going beyond academia and shaping dialogues between various communities. She noted that "Sociologists are really important. We can contribute to the debate on social problems," and called for an active participation in changing social reality through addressing social problems and improving people's lives. Harold Zborovsky, a vice-president of the Russian Society of Sociologists and a professor at UrFU, focused on regional inequalities in higher education in light of the increasing social and economic uncertainty in Russia. Basing on his recent research, Zborovsky suggested replacing an existing linear model of higher education with an authoritarian management by a non-linear one, which is connected to the 
development of interactions between local communities and horizontal ties between universities in Russian regions (read more in: Zborovsky, 2016). His argument about building strong professional networks and the self-organization of university communities sounds reasonable, especially in the context of the unequal distribution of resources and increasing pressure upon sociologists in Russia. At the same time, this thesis resonates with Abraham's call to coalesce in the struggle against global inequalities. In contrast, Mikhail Gorshkov, a director of IS RAS, gave another opinion in pointing out that sociologists should examine reality, but not change it. However, he welcomed Abraham's invitation for international cooperation, and announced that Russia was ready to host the ISA World Congress of Sociology.

Burning issues including the reduction of social welfare, the low living standards of the elderly, restricted rural mobility, class inequality, and ethnic tension were among the main topics of the "Problems of Russian Society: A View of Young Scholars" session, organized by the Young Scholar Council of IS RAS. The session brought apprentice sociologists together from different cities such as Yekaterinburg, Magnitogorsk, Moscow, and Novosibirsk, and aimed to enhance the professional level of participants through discussion. It means that the organizers of this session not only accepted high-quality papers, but also invited motivated young scholars whose applications were not as strong. The exchange of professional experiences revealed the problem of inequalities inside the Russian sociological community. The differentiation of papers in labeling them as "strong" and "weak" can be explained by an unequal distribution of economic, cultural, intellectual, and other resources. It is not a secret that the leading sociological research centers are mostly concentrated in large Russian cities.

A lack of organization and the complicated structure of the UrFU building made it difficult to understand where and when a session, a panel, or a round table one was interested in would be held. However, a flexible program opened up an opportunity for selforganization and restructuring the event during its processing. A democratic atmosphere allowed us to hold an unplanned joint session of the Young Scholar Council of the IS RAS and the Young Working Group "Sociology in Public Space and Trust in Society", initially designed by Elena Zdravomyslova. At this joint session, we and our colleagues gave a workshop to UrFU students, explaining how to identify social problems, how to redefine them in sociological terms, and how to find the ways of addressing these problems. We asked the participants to split into three teams with each team accompanied by two researchers, and to formulate the relevant social problems from the perspective of Public Sociology. While presenting the teamwork results, students spoke about the unreasonable public administration in Russia, the difficulties in finding jobs for youth in Russian regions, and the urban transport challenges in Yekaterinburg. The outcome of such an improvisation was described well by one of the moderators: "For the participants of our workshop it is not a problem now to formulate a social problem, to elaborate a research methodology, to look at things through the lens of Sociology..." (Pavel Sushko, 19.10.2016).

Other events which I attended within the Congress were dedicated to the exploration of social structure and social mobility, as well as to the methodology of quantitative 
and qualitative research. The panel on "Transformations of Social Structure and Social Inequality," chaired by Zinaida Golenkova, is remembered for the paper by Roman Anisimov, and the subsequent discussion on the precariat as a new social group in Russian society. The term 'precariat' was introduced for the first time by the economist Guy Standing in 2011, and means "the new social class" distinguished by an unstable position and vulnerable employment (Standing, 2011). However, since then, a dispute over this term continues. Two views regarding the precariat were put forward by the panel. Some participants opined that the precariat contained only those people who relied on the support of the state as manifested by social welfare and benefits, while others argued that it also included those whose income might be relatively high. Sociologists did not agree on the meaning of this term. What was clear, though, is that this discussion drew attention to the differentiated nature of the precariat, and showed the necessity of further examination. Other speakers of the panel explored various topics in their presentations, ranging from the transformation of the Mongolian social structure (Damdin Badaraev) to gender inequality in Russia (Elena Kranzeeva).

Three panels on sociological research methods were held in parallel. These were "Methodological and Methodical Aspects of Using Qualitative Sociological Data," moderated by Oleg Bozhkov and Boris Doktorov, "Modeling of Social Phenomena," chaired by Yuliana Tolstova, and "Mass Surveys: Methodical Problems, New Directions and Enhancement of the Approach," which was organized by Mikhail Kosolapov and Galina Tatarova. Unfortunately, it was impossible to attend them all, so I had to choose one. The panel on mass surveys drew my attention, as far as it addressed the issues of new methodologies. For instance, one of the contributors of this panel, Olga Savinskaya, spoke about the mixed-methods research strategy. She described the stages of the development of this "third" methodology, supposing the combination of quantitative and qualitative approaches (Savinskaya, 2016: 8467). Despite the term "mixed methods" becoming an integral part of the international sociological discourse, it still sounds awkward when we try to find the equivalent in the Russian language. In the course of the subsequent discussion, sociologists raised the questions regarding the incompatible logics of the methods to be mixed. Like the previous paper, the presentation by Mikhail Kosolapov was dedicated to the combination of research designs in mass surveys, especially in longitudinal studies. This paper attracted much interest from the audience because the presenter explained which specific research designs could meet the analytical goals of various types of longitudinal survey in detail. In his concluding remarks, Kosolapov suggested applying "hybrid designs" (or mix-mode methodologies) allowing for the enhancement of the procedure of longitudinal study and the quality of the data obtained. Other speakers considered such questions as an application of projective techniques (Zhanna Puzanova), and a heuristic potential for the examination of subjective well-being (Galina Tatarova, Anna Kuchenkova).

The issues of longitudinal studies also were a key topic for Round Table 26, "Longitudinal Quantitative and Qualitative Research on Social Inequality: The Processual Approach," which was brilliantly moderated by Lara Petrova. In her talk, Olga Tereschenko, 
the first contributor, beautifully explained the differences between methodological approaches to the measurement of social inequality, and distinguished the two schools of longitudinal studies. She argued that the American school focused mainly on the examination of social mobility and professional prestige, while the British school centered on the exploration of health records and medical notes. Additionally, Tereschenko highlighted three types of quantitative data, those of a) cross-sectional, b) panel, and c) event history data. The last type provides a basis for an event history analysis to be conducted in longitudinal studies (Tereschenko, Koroleva, 2016: 10433). The next speaker from the Public Opinion Foundation (FOM) ${ }^{1}$, Maria Ozerova, shared her methodical experience of realizing a longitudinal study on social differentiation in education. She stated that the researchers from FOM's project were faced with the respondents' retention in the $4^{\text {th }}$ wave because of their relocation. Such a problem leads to a restructuring of the general sample and needs a combination of research methods such as telephone and online surveys, which helps to increase the accessibility to respondents and minimize the effects from sample deformation (Ozerova, 2016: 10411).

Tatiana Bogomolova gave an unplanned talk on panel data as a basis for the longitudinal study of economic mobility, which was understood as a change in individual's income in time. The speaker distinguished three types of surveys: a) a retrospective crosssectional survey, b) a repeated survey with independent samples, and c) a longitudinal survey. In addition, she identified the problem of the "consistent" sample depletion in economic mobility studies. The last speaker, Vera Kharchenko, dedicated her presentation to the analytical reflection on the usage of the Russian Longitudinal Monitoring Survey (RLMS) realized by the Higher School of Economics (HSE) and ZAO Demoskope, together with the University of North Carolina and the IS RAS. The presenter put forward several assumptions about a), a narrow group of Russian authors making publications based on RLMS, b), the affiliation of these authors with the one institution, and c), a lack of methodical reflection on how to use the RLMS data base. Thus, in her talk Kharchenko problematized the access to longitudinal data: while the RLMS is formally open, in fact, it remains a "private" data base. A friendly professional atmosphere made a productive discussion possible. As Lara Petrova then wrote on Facebook, "It was very interesting to listen to and to discuss! Among the ideas, which we have 'cultivated,' were the problems of activity in usage of longitudinal data and data quality, an interviewer effect, a few methodical publications on longitudinal studies, a marketing rhetoric in longitudinal studies... unequal chances to remain in a longitudinal sample, a social differentiation of panel retention, a 'privacy' of the longitudinal data base as a monopoly over knowledgel data..." (Lara Petrova, 21.10.2016).

I partook in Panel 27, "Social Mobility: Objective and Subjective Aspects," chaired by Victoria Semenova and Mikhail Chernysh, and which was the last panel of the Congress. It was organized by the research team of the project "Intergenerational Social Mobility From the $2 \mathrm{O}^{\text {th }}$ to $21^{\text {st }}$ Century: Four Generations of Russian History." The speakers pre-

\footnotetext{
1. A Russian market research company based in Moscow.
} 
sented the results of their research inspired by the longitudinal project "Paths of a Generation" (1983-1993), by Mikk Titma. However, the new complex study on social mobility had its specific research design supposing a combination of quantitative and qualitative methods. I will outline the most interesting points presented by the panel. In his speech, Mikhail Chernysh explained that social mobility in contemporary Russian society occurred mostly between generations, while the level of intragenerational mobility became relatively low. In addition, he drew attention to the problem of social reproduction, meaning that the younger generations had fewer chances for social mobility compared to their parents' generation. Similarly, in her paper, Yulia Epikhina noted that inequality in the Russian educational system has increased in recent years. Her quantitative analysis showed a slowdown of educational mobility which can be explained by the decline of structural mobility. Anna Strelnikova continued the reflection on social mobility through the lens of educational trajectories. Her analysis of both biographical interviews and survey data allowed to formulate a question about "status inconsistency." Unlike Western countries, the level of formal education in Russia does not correlate with the level of knowledge. This means that respondents with the same educational status might belong in different social classes, and have distinct life-styles (read more in: Semenova, Chernysh, Vanke, 2017: 184). Finally, Victoria Semenova considered theoretical approaches to subjective social mobility, and outlined the perspectives of the application of these approaches in empirical research. She suggested understanding subjective social mobility as an individual's perception of his/her social position, and showed how to build a typology of professional careers applying the basic principles of grounded theory in detail.

In summary, the Congress has shown that sociologists in Russia follow global trends in examining urgent social problems, as well as reflecting on methodological issues such as the application of new approaches in inequality studies. The discussions have also demonstrated that the fight between the supporters of quantitative and qualitative approaches is over. The sociological debate has brought the need of reflection on the application of mixed, hybrid, and combined methodologies in the study of local and global inequalities, as well as inequalities inside the field of Sociology, into sharp focus. At the closing plenary session, Margaret Abraham once again called sociologists to action against social injustice, and raised the problem of the increasing pressure on Sociology in Russia. She announced that the International Sociological Association expressed its support for the pollster Levada Center, which was recently included on the list of "foreign agents," literally meaning "unwelcomed" non-commercial organizations, by the Russian Ministry of Justice. Continuing on this theme, Elena Zdravomyslova pointed out that more than seven sociological centers in Russia have been currently recognized as "foreign agents." Besides Levada, the list includes such reliable professional organizations as the Center for Independent Sociological Research in St. Petersburg, the Samara Center for Gender Studies, and others. Zdravomyslova's call to speak publicly about academic freedom resonated with Zborovsky's warning at the opening of the Congress "not to shoot at sociologists," because sociologists can really help society. It is obvious that the solution to the 
problem of the restriction of academic freedoms can be found in professional solidarity and is the responsibility of everyone who belongs to the sociological community.

\section{References}

Ozerova M. (2016) Longitjud kak istochnik dannyh o social'noj differenciacii v obrazovanii: metodicheskij opyt FOMa [Longitudinal Survey as a Source of Data on Social Differentiation in Education: The Methodological Experience of the Institute of Public Opinion Foundation]. Sociologija i obshhestvo: social'noe neravenstvo i social'naja spravedlivost': Materialy V Vserossijskogo sociologicheskogo kongressa (Ekaterinburg, 19-21 oktjabrja 2016 goda) [Sociology and Society: Social Inequality and Social Justice: The Proceedings of the 5th All-Russian Sociological Congress (Ekaterinburg, October 19-21 2016)] (ed. V. Mansurov), Moscow: Russian Society of Sociologists, pp. 10411-10421.

Savinskaya O. (2016) Strategii smeshivanija metodov (Mixed Methods Research): obzor sovremennyh diskussij o formirovanii "metodologicheskogo dvizhenija" [Mixed Methods Research: The Review of Current Discussions on the Third Methodological Movement]. Sociologija i obshhestvo: social'noe neravenstvo i social'naja spravedlivost': Materialy $V$ Vserossijskogo sociologicheskogo kongressa (Ekaterinburg, 19-21 oktjabrja 2016 goda) [Sociology and Society: Social Inequality and Social Justice: The Proceedings of the 5th All-Russian Sociological Congress (Ekaterinburg, October 19-21 2016)] (ed. V. Mansurov), Moscow: Russian Society of Sociologists, pp. 8467-8475.

Standing G. (2011) The Precariat: The New Dangerous Class, London: Bloomsbury Academic.

Tereschenko O., Koroleva I. (2016) Issledovanija social'nogo neravenstva: processual'nyj podhod [Social Inequality Research: Process Approach]. Sociologija i obshhestvo: social'noe neravenstvo i social'naja spravedlivost': Materialy V Vserossijskogo sociologicheskogo kongressa (Ekaterinburg, 19-21 oktjabrja 2016 goda) [Sociology and Society: Social Inequality and Social Justice: The Proceedings of the 5th All-Russian Sociological Congress (Ekaterinburg, October 19-21 2016)] (ed. V. Mansurov), Moscow: Russian Society of Sociologists, pp. 10427-10436.

Semenova V., Chernysh M., Vanke A. (eds.) (2017) Social'naja mobil'nost'v Rossii: pokolencheskij aspect [Social Mobility in Russia: Generational Aspect], Moscow: Institute of Sociology RAS.

Zborovsky G. (ed.) (2016) Nelinejnaja model' rossijskogo vysshego obrazovanija v makroregione: teoreticheskaja koncepcija i prakticheskie vozmozhnosti [Non-linear Model of Russian Higher Education in the Macro-Region: Theoretical Approach and Practical Perspectives], Ekaterinburg: Gumanitarnyj universitet. 


\title{
Социологическая дискуссия о неравенстве в России и за ее пределами
}

\author{
Александрина Ваньке \\ Кандидат социологических наук, доцент социологического факультета Государственного академического \\ университета гуманитарных наук, научный сотрудник Института социологии Российской академии наук \\ Адрес: ул. Кржижановского, А. 24/35, К. 5. Москва, Российская Федерация 117259 \\ E-mail: alexandrina.vanke@gmail.com
}

Обзор посвящен V Всероссийскому социологическому конгрессу, состоявшемуся в Уральском федеральном университете в Екатеринбурге в октябре 2016 г. Мероприятие под названием «Социология и общество: социальное неравенство и социальная справедливость» привлекло более 1000 участников из России и зарубежных стран. Конгресс проходил на фоне усиления неравенства в России, ставшего результатом экономического кризиса 2015 г. Программа состояла из 17 сессий, 37 секций и 35 круглых столов, в ходе которых рассматривались такие острые темы, как неравное распределение ресурсов в российских регионах, уменьшение социальной поддержки, низкий уровень жизни незащищенных социальных групп, рост этнического напряжения и другие. Один из пленарных докладов был сделан президентом Международной социологической ассоциации, Маргарет Абрахам, которая говорила о гуманистической миссии социологии и призвала слушателей объединяться в борьбе против социальной несправедливости в мире. Дискуссии на Конгрессе показали, что социологи в России следуют за глобальными трендами в том, что касается изучения острых социальных проблем, а также - рефлексии относительно методологических вопросов, например, применения новых подходов в исследованиях неравенства. Дебаты о сужении академических свобод в России на заключительном пленарном заседании отчетливо дали понять, что решением данной проблемы может стать профессиональная солидарность и ответственность каждого, кто чувствует свою принадлежность к социологическому сообществу.

Ключевые слова: социальное неравенство, социальная справедливость, социальные проблемы, социологическое сообщество, социология, российская социология, международная социология 